$\stackrel{N / E}{N}$

Global Journals Inc

inte

\title{
The Services Marketing Mix: Theoretical Views of Church Services Marketing
}

\author{
By Rufus O. Adebayo \\ Durban University of Technology
}

Abstract- It could be noted that marketing can be stretched beyond profit business organisation. In the area of services, it is important to note that both profit and non-profit organisations share competitive traits in the sense that they are competing with one another advantageously to distinguish themselves. Thus, this paper reviews the existing literature on services marketing and highlights opportunities for competitive-oriented church activities for improved church marketing. These activities are simplified in this review by first identifying, the theoretical implications and then presenting an overview of the services marketing mix ingredients. Although the variety of ways in which services marketing mix are construed is enormous, some relevant studies on services marketing mix and studies with church efforts to implement the principles of services marketing mix are the focus of this theoretical paper. Thus, the 7Ps of services marketing, which is an extension of the original marketing mix from four to seven elements, is discussed.

\section{GJMBR-A Classification: JEL Code: M39}

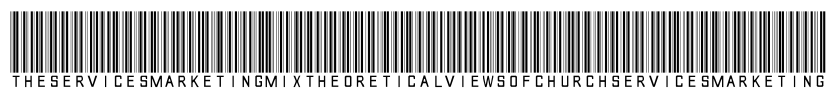

Strictly as per the compliance and regulations of:

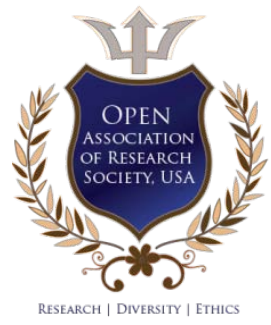

(C) 2021. Rufus O. Adebayo. This is a research/review paper, distributed under the terms of the Creative Commons AttributionNoncommercial 3.0 Unported License http://creativecommons.org/licenses/by-nc/3.0/), permitting all non commercial use, distribution, and reproduction in any medium, provided the original work is properly cited. 


\title{
The Services Marketing Mix: Theoretical Views of Church Services Marketing
}

\author{
Rufus O. Adebayo
}

\begin{abstract}
It could be noted that marketing can be stretched beyond profit business organisation. In the area of services, it is important to note that both profit and non-profit organisations share competitive traits in the sense that they are competing with one another advantageously to distinguish themselves. Thus, this paper reviews the existing literature on services marketing and highlights opportunities for competitive-oriented church activities for improved church marketing. These activities are simplified in this review by first identifying, the theoretical implications and then presenting an overview of the services marketing mix ingredients. Although the variety of ways in which services marketing mix are construed is enormous, some relevant studies on services marketing mix and studies with church efforts to implement the principles of services marketing mix are the focus of this theoretical paper. Thus, the 7Ps of services marketing, which is an extension of the original marketing mix from four to seven elements, is discussed.
\end{abstract}

\section{INTRODUCTION}

T his study provides insight into how services marketing can be applied to non-profit organisations and in the area of service quality within a given market. Gawroński and Majkowska, (2018) state that the greatest doubts may arise from the effects of church marketing. Apart from doctrinal ethical concerns regarding the marketing of faith and religion, doubts arise as to how marketing can affect the future of the Church. Adebayo (2015) mentions that it is worthy of note that some Christian church activities and marketing activities are interconnected. According to Appiah, Dwomoh, and Kyire (2013), using marketing elements to promote religious services has become a top bracket business. Thus, the influence of marketing on the nonprofit organisation (the church in this case) is provided to identify reasons for non-profit administrators to be involved in various marketing systems and for the use of certain operating principles. Van der Merwe, Grobler, Strasheim, and Orton (2013) acknowledge that the marketing of service is more challenging than the marketing of a product because selling a product that consumers can see, feel, and touch is easier than selling an intangible service, such as banking services. According to Brandenberg (2014), service marketing is generally focused on a specific target market, such as business travellers or leisure travellers.

Author: Durban University of Technology, Faculty of Arts and Design, Department of Media, Language, and Communication, 4001, Durban, South Africa. e-mail: rufusa@dut.ac.za
In addition, according to Johnston (2014), when you sell a service, you sell an intangible. One does not have to limit his/her pitch to pre-existing features because one can adjust the features of the service to meet the needs of each client or customer. Thus, this study emphasises aspects of service that solve one's prospect's problems or satisfy one's needs and how one can offer a trial period for using services. This approach is reviewed in this study and it seems obviously suited to making religious services more accessible. Beckwith (2013) argues that the approach of service makes marketing easier, cheaper, and more profitable. In addition, the key to any selling is to focus on the business needs/pains of the prospective consumer. This formed implication for this review and to establish how the service uniquely benefits people and show the ways service organisations (non-profit organisations) provide value for their business.

\section{il. Theoretical Views of Distinctive Characteristics of Services - The Church}

Services marketing is different from traditional product marketing. There are outputs from the services marketing literature that depict four service characteristics: intangibility, inseparability, heterogeneity, and perishability. These characteristics show how services marketing are distinct from the marketing of product. According to An (2014), one of the distinctive characteristics of services is intangibility, which refers to the inability to assess the value gained from engaging in an activity using any tangible evidence. Intangibility has become a complex concept in the marketing of services. Boundless (2014) asserts that when a customer is buying a service, he/she perceives a risk related to the purchase. It is difficult for a customer to know in advance what they will be getting. To reassure the buyer and build their confidence, marketing strategists need to give tangible proof for the quality of service. Adebayo (2020) adds to this by comparing the act of shopping for tangible products within a given 'marketplace' and shopping for 'salvation' (including the selling and promotion of merchandise and services at churches). It is also noted in Christendom that walking by the spirit is the outward manifestation, in action and speech, of living by the spirit/holiness (Galatians 5:16). The Bible in Ephesians 6:12-13 says 
"For our struggle is not against flesh and blood, but against the rulers, against the authorities, against the powers of this dark world and against the spiritual forces of evil in the heavenly realms. vs13 - Therefore put on the full armour of God, so that when the day of evil comes, you may be able to stand your ground, and after you have done everything, to stand." The Bible reveals that Paul removes much of the intangibility of spirit-fruit by cataloguing precisely what he means in Galatians 5:22-23, namely, love, peace, kindness, goodness, faithfulness, gentleness, and self-control. This collective list of fruit identifies the character of Christ; therefore, it is the character of Christ that grows in Christians as visibly evidenced by these fruits.

Senthil, Dharmalingam, and Panchantham (2011) state that inseparability reflects the interconnection among the service provider, the customer involved in receiving the service, and other customers sharing the same experience. According to Black, Childers, and Vincent (2014), when the production and consumption process occur concurrently, many additional factors can change the service outcome and, therefore, the perceived service quality. These include the customer's role as coproducer, their connection with the employee, and the customers' connection with other customers. Vance (2014) reveals that it is because of the principle of inseparability that the success of a service-based business will largely depend on the quality of its salespeople, customer service representatives, or other front-line employees who deal with the customers. The preacher/evangelist/pastor stands as a service provider in the case of a church, but it is worthy of note that the attributes of God (such as holiness and love) must reflect in the characteristics of a preacher (God is the owner of the service - the producer and the source of the power - Psalm 62:11). Thus inseparability in terms of church services certainly involves the power of God. The power of God is that ability and strength whereby $\mathrm{He}$ can bring to pass whatever He pleases, whatever His infinite wisdom may direct, and whatever the infinite purity of His will may resolve. Without power, His mercy would be but feeble pity, His promises an empty sound (Pink 2014).

Heterogeneity or variability of service arises from the difficulty in standardizing services (Moeller 2010). The idea is that when different people are involved in delivering the service, services cannot be homogenous in the same way that goods can be (Adebayo, 2015). Roy and Sivakumar (2014) opine that the greater the labour and knowledge content, the greater is the variability, and thus the focal organisation deploys considerable operant resources to ensure that heterogeneity is well managed. In contrast, heterogeneity in the provision of both services and tangible output in Christendom is God's power alone. It is important to point out that God's servant underscores the power necessary to effectively communicate God's message. In order words, management of heterogeneity in Christendom is quite different from that proposed by Silvakumar; in Christendom, management of heterogeneity does not depend on the amount of education or any other advantages one may have but depends on the cooperation of the Spirit of God.

Moeller (2010) argues that perishability means that services cannot be stored or stockpiled. Abon and Adebayo (2020) state that services are meant to be consumed by consumers and yet such services could still be re-packaged in a better way and delivered more acceptably. However, the perishability of the outcome at the end of the consumption process is important when looking at goods. Moeller (2010) adds that perishability is not only associated with the outcome of service, but also with the service provider's capacity. Taking our lead from Moeller, perishability in Christendom can be viewed in two ways: from the perspective of the service provider (a preacher/pastor) and from the perspective of the consumer (congregant/unsaved). The former is believed not to force the truth upon the hearers nor attempt to impose right action upon the congregants. The perishability or the sustainability of the word of God may not only be the message that answers congregant's needs but also the possession of power that gets the message through to the congregants.

\section{ili. An Overview of the Service Marketing Mix Ingredients}

As noted earlier in this study, one of the approaches is to look at a non-profit organisation in service marketing. Unlike typical profit-seeking businesses, non-profit organisations exist for reasons other than making a profit and usually (unknowingly) engage in marketing (Lamb, Hair, and McDaniel, 2013). Churches can, therefore, be described as non-profit organisations that offer a service to a congregation (Van der Merwe et al. 2013; Shawchuck, Kotler, Wrenn, and Rath, 1992). There are a number of perceptions of the concept of the service marketing mix within the business and marketing literature. Therefore, it is relevant to consider how the traditional mix alters for a service through these 7Ps. This is because the additional 3Ps have gained widespread acceptance in services marketing literature. After all, most service organisations market more than one service (Kar, 2010; Abon and Adebayo, 2020). This may involve deciding what new services to introduce to which target market, what existing services to maintain, and what services to eliminate. An overview of the service marketing mix ingredients are discussed below: 


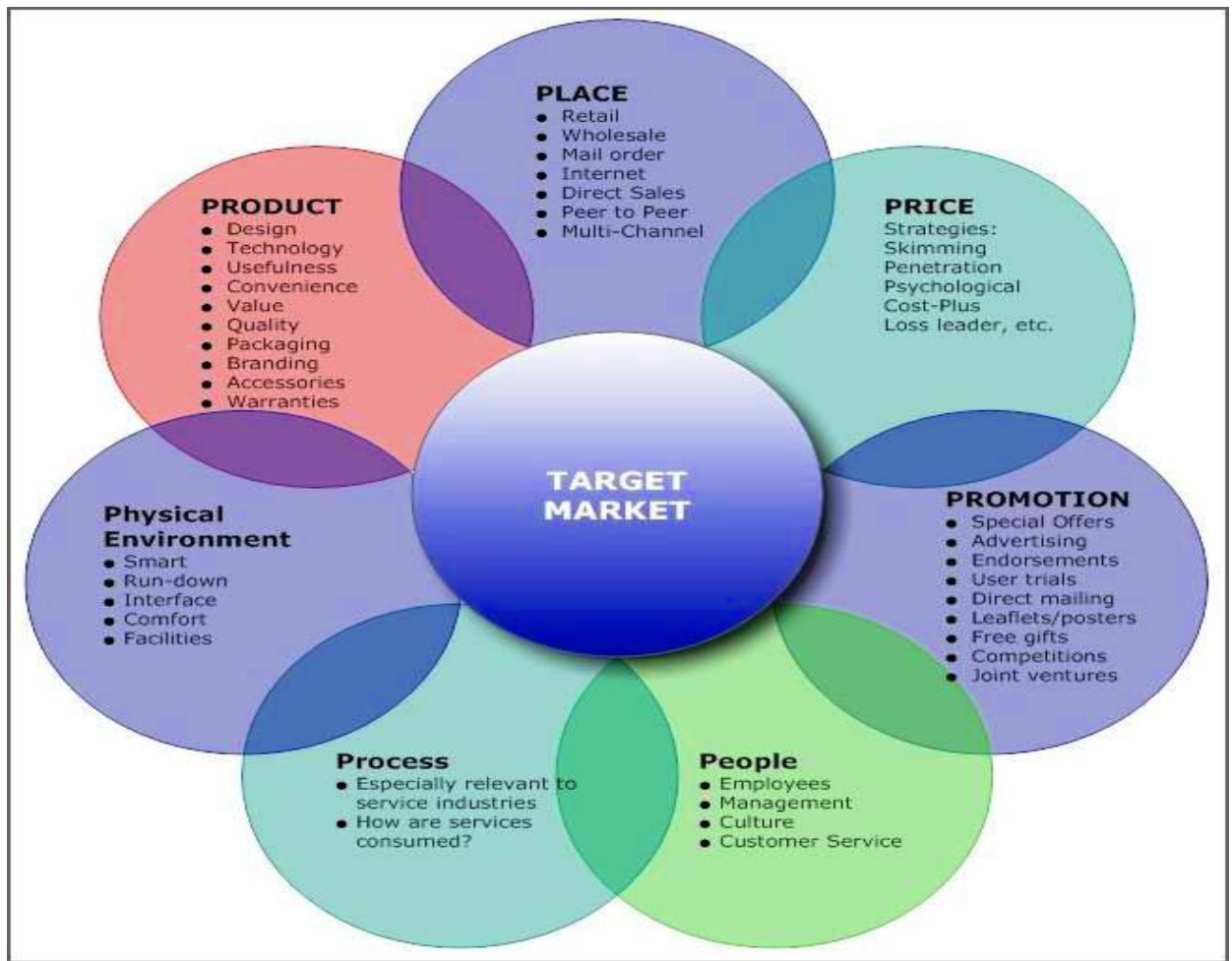

Source: Adapted from Kar, 2010:11

Figure 1: Services marketing mix model - 7Ps

The services marketing mix is called the 7Ps as seen in Figure 1.1 above. This services marketing mix extends the traditional marketing mix model (4Ps) to seven elements. It gives a picture of a product or price mix of an organisation, in combination with a promotion plan so it can approach and serve customers based on well-considered distribution and customer contact channels (Van Vliet 2011:2). In addition to the four traditional elements, three important elements have been added: People, Process, and Physical Evidence, that make up the services marketing mix - 7Ps. The combination of four elements and the three elements to make up seven elements of the services marketing mix are discussed below concerning the church use of marketing.

\section{a) Product}

According to Palmer (2011), products are how organisations seek to satisfy customer's needs. It is anything that the organisation offers to potential customers, whether it is tangible or intangible. Services are very different from products (Kar, 2010). Based on commercial marketing, Kotler and Armstrong (2012) define service as any activity or benefit that one party can offer to another that is essentially intangible and does not result in the ownership of anything. In profit marketing, a product is generally believed to be a tangible product purchased by the customer. Donovan and Henley (2010) express that in some cases, a mix of tangible products and services is purchased. This implies that the products and services are purchased because of the benefits they provide to the buyer. A framework that ties these two concepts (customer benefits and product or service attributes) together is the levels of product and services (Kotler and Armstrong 2012). Each level adds more customer value and they are core products, which raises the question: what is the buyer really buying? The second level is the actual product which sees the features, design, brand name, and packaging. The third level is to build an augmented product around the core benefit and actual product by offering additional consumer services and benefits. 


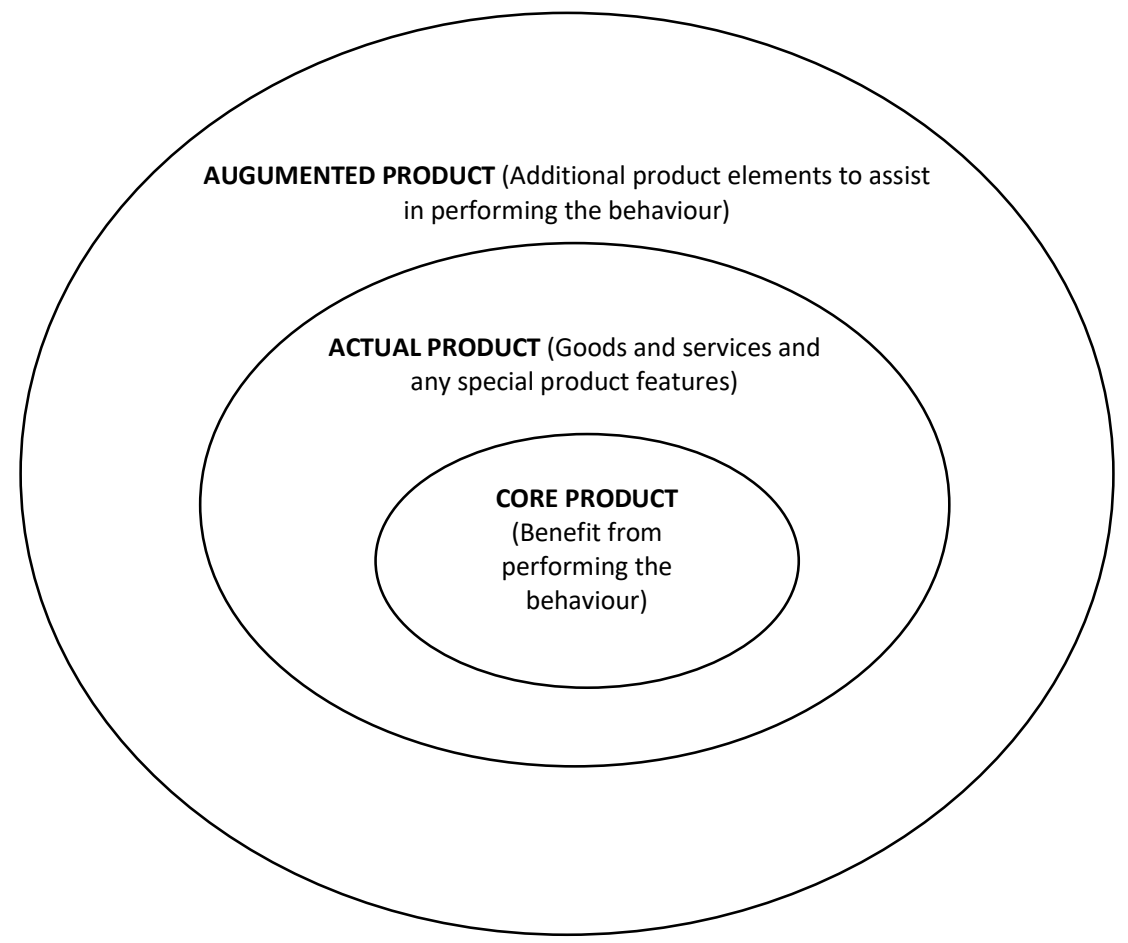

Source: Adapted from Kotler and Lee (2011)

Figure 2: Kotler and Lee's three levels of the social marketing product

In this study, particular attention is given to services in line with social marketing products as illustrated in Figure 2. In this case, questions that can be raised here according to Lee and Kotler (2011) could be: What's in it for the customer to adopt the behaviour? What benefits will the congregations receive? What needs will the desired behaviour satisfy? What problems will behaviour change solve? The first level shows the benefit from performing a particular behaviour, the second level indicates goods and services and any special product features, while the third level reveals opportunities for additional product elements to assist in performing the behaviour. These three levels are discussed in relation to the church as follow:

\section{Core Product}

As noted by Lee and Kotler (2011) the core product is not only the behaviours or accompanying goods and services to be developed, provided, and or promoted. It is also the benefits the audience (congregation, in the case of church) wants and expects to experience when they perform the behaviour. Core products can stress benefits from the desired behaviour or perceived costs of the competing behaviours that the desired behaviour can help the target audience avoid. However, according to the marketing concept, an organisation should try to provide products that satisfy customers' needs through a coordinated set of activities that also allow the organisation to achieve its goals (Hult, Pride, and Ferrell 2012). Over the course of history, the religious product is often an important component of one's worldview. Accordingly, religious beliefs can not only direct social action but can influence social change (Engelland 2014). For example, Njoh (2012) argues that religious influence can be successful in promoting change in two directions: a radical change in which a society is pushed to a new direction; and conservative change, in which a society is encouraged to return to the social arrangements of the past. In this sense, returning to the social arrangement of the past could mean that the church's 'core product' is eternal salvation (Adebayo and Govender, 2015). One point of convergence between core product and eternal salvation is that there is a promise that follows the benefit of performing the behaviour. Abon (2020) sums up that products are delivered through services. For instance, sermons focus on eternity and worship services are designed to sell core products (David 2014; Adebayo and Govender, 2015).

\section{Actual Product}

In another dimension, the desired benefits the consumer sees in the core product can be turned into product attributes that represent the actual product. The actual product is described as having up to five characteristics (Strydom, 2011; Lee and Kotler, 2011). First, the actual product has certain features. Second, it has certain styling (or design). Third, it also has a certain quality level; it is made well or badly. Fourth, it has a certain packaging. Fifth, it has a brand name. It is in this light that one queries whether salvation can be considered as a product or not. There is a clear indication that there is a similarity in the process where a consumer purchases products and a member of a 
congregation obtains religious salvation. One could point out that salvation was a sovereign act of God it is a spiritual gift manufactured by God. "You are a Christian not because of something you did, but because of something God decided" (Adebayo and Govender 2015). On the contrary, what can be considered as the actual product can be traced to a model of preaching (product feature) that can be suitable for this present generation of Christians holding on to spiritual guidance. In addition, since there is a value involved and profit/reward is attached to salvation, the actual product can be an act of building relationships (Adebayo, 2019). This suggests a new way of consumers seeking products to satisfy their needs and wants. Likewise, congregations seek a spiritual connection to what will liberate them from bondage, for wholeness, and the solution to unending problems. This is the actual salvation Christianity, at its best, offers them.

\section{Augmented Product}

Similarly, benefits that go beyond the tangible product could be offered to the target market with additional services. According to Strydom (2011), an augmented product is sales support features, such as delivery, installation, warranties, and services. Although these are considered optional according to some writers, they are sometimes exactly what are needed to provide encouragement, remove barriers or sustain behaviour (Lee and Kotler, 2011). The product could also add to its opportunities by creating more attention, appeal, and memorability for target audiences. Rothschild's (2009) arguments centre on the marketing concept of exchange and its function as a stimulusresponse process. Therefore, if a person accepts the concept of exchange as critical to marketing, the behaviour and the product cannot be the same thing. Products are the tools that social marketers use to realise the desired behaviour change (Adebayo, 2015). In addition, the church concept of augmented products reflects social ministry. Amelia and Tonya (2010) describe four social ministry types: (1) relief services (e.g., giving a hungry person a fish); (2) personal development (e.g., teaching a person to fish); (3) community development (e.g., giving people fishing equipment); and (4) systemic change (e.g., helping everybody get fair access to the fish pond). They further note that such ministries can be described by their focus of action (e.g., individual versus corporate) and the nature of the benefit provided by the ministry (e.g., direct versus indirect). Social action, for creating social change (augmented product) as noted here, requires that churches should address manifested needs and situations that give rise to those needs (Adebayo, 2015).

\section{b) Price}

In marketing, the concept of pricing may be ambiguous, especially when laying emphasis on nonprofit sectors. Adebayo (2019)argues that the virtual neglect of some significant characteristics of marketing such as the exchange process, and pricing from the religious perspective might affect the church as a nonprofit organisation. Like for-profit marketing, a non-profit marketer can use various pricing tactics to make the desired behaviour appear to have fewer costs and more benefits while making the undesired behaviour have less benefit and greater cost. Non-profit marketing in another sense could be more complicated and there are more factors involved. Moreover, pricing has great relevance for commercial marketing products, which determines the way the business can generate an income to pay all the costs incurred in the development and distribution of the product or service (Strydom, 2011).Also, as marketing strongly influences the work and mission of public and non-profit organisations, not-for-profit organisations with limited purchasing power such as churches, universities, charitable organisations, and government agencies need to price carefully (Kotler and Keller, 2012). When the products are not visible, a price is to be incurred in exchange for receiving a bundle of benefits (from this invisible product) (Thackeray and Brown, 2010). Adebayo (2019) states that sacrifice is all it takes in the area of spiritual cost; it establishes a relationship with the sacred by purifying and preparing the sacrificer. In the case of the church, products such as Christian music, Bible study manuals, and Sunday school manuals can be exchanged for money, while individual time and material possessions can be donated to the church in exchange for good feelings and other non-monetary rewards. Thus, the exchange is not necessarily a purely commercial transaction and involves more than the exchange of money only for goods and services (Adebayo, 2019).

c) Place

According to the Chartered Institute of Marketing (2009), a place is where customers buy a product and the means of distributing the product to a particular place. Furthermore, the product must be available in the right place, at the right time and in the right quantity, while keeping storage, inventory, and distribution costs to an acceptable level. For an intangible product, place refers to decisions about the channels through which consumers are reached with a particular service or information. In addition, the place influences the service buyer's satisfaction and often offers a different side of value (utility) to the consumer (Kar, 2010). This could mean that closer to the consumer means a higher probability of sales. In services marketing, a place could be where your services are offered, and where you have a presence. There are few decisions to be considered regarding the term place in service marketing. Moreover, the bottom line is that service providers have to ensure that services are successfully delivered to customers. 
The same principles of making access and delivery easy also apply to non-profit marketing. The issue of convenience is also resonating, especially, when relating to the subject (the church) of this study. Lamb, Hair, and McDaniel (2013) express that a key factor influencing the selection of a service is convenience. This implies that there should be a decision on whether to distribute services to end-users directly or indirectly through other firms (Adebayo, 2020). According to Kotler and Keller (2012), the marketplace is physical, such as a store you shop in; market space is digital, as when you shop on the internet. Adebayo (2020) adds that a place of worship on the other hand could literarily mean a designed structure (with a specific symbol) or consecrated space where individuals or a group of people such as a congregation can come to perform acts of devotion, worship, or religious study. According to Desa (2013), most places of worship (temples, mosques, churches, holy sites, and so forth) have one thing in common, regardless of religious affinity: they are meant, by people, as sacred sites. Suri and Rao (2014) add that the number of people that visit religious places such as Rome, Varanasi, Mecca, Medina, Kashi, etc. is increasing every year. One may realise that congregants find spiritual value in a wide range of places, which is what makes a place a "place of worship". "Places of worship" is an inclusive term that includes churches, mosques, synagogues, temples, chapels (e.g., within convents or seminaries), shrines, meeting houses, or other places of assembly for religious purposes (Suri and Rao, 2014).Thus, Christian churches could be considered as a place of worship. However, natural or structural landscapes may also be considered as places of worship, and for believers or religions, can be considered holy (Adebayo, 2020). From all indications, it is obvious that the concept of accessibility is more important than the traditional defined place. One important factor that shows the relationship between Christian place of worship and marketplace is convenience as identified by Lamb, Hair, and McDaniel (2013). This concept of convenience recognises not only the location of service outlets but, more importantly, how the consumer is to be designed into the service production-consumption process, and who is to be involved in that process (Palmer, 2011).

\section{d) Promotion}

Marketing is not sales, nor is it advertising. It is a sequence of steps to create value. And value is everything that is desired and valued by an individual or a community. The creation of value according to the study by Simões and Nascimento-e-Silva (2020), is done through the establishment of communication channels - promotion. Marketing is done through communication, dialogical interaction, therefore, which starts from institutions for individuals, organizations, and other institutions with a well-defined purpose. Traditionally, the hierarchy of strategies employed by businesses starts with the marketing mix, which involves activities such as designing the product, including its package, pricing of the product, as well as terms of sale, distribution of the product, including placing it in outlets accessible to customers; and promoting and communicating about the product (Kotler and Keller, 2012; Strydom, 2011).

Promotion or marketing communication is the home base for advertising, along with public relations, sales promotions, personal selling, packaging/point of sales, and direct marketing. Understandably, each of these promotional techniques has its own set of capabilities, some of which complement each other, some of which duplicate each other's efforts. However, communications must be viewed more broadly than just media advertising, public relations, and professional salespeople. According to Shimp and Andrews (2013), communication is the process whereby commonness of thought is established, and meaning is shared between individuals or between organisations and individuals. According to Adebayo and Govender (2015), the adoption of marketing communication, and social media strategies are becoming more prevalent in the routing services of some contemporary churches. Blake (2021) reveals that the Church's approval of media relations and the utilization of practical measures of social communication have become one of the reasons for growth in the acceptance of marketing promotion between pastors and members. In addition, the advancement of Christian leaders" approval of social media has led to the theory of marketing the church (Gawroński \& Majkowska, 2018). Social media marketing and platforms have allowed organisations to instantaneously direct information and receive their investors' response immediately, without encountering significant traditional communication expenses (Lee, Hosanagar, and Nair, 2018).

\section{e) People}

According to Wilson, Zeithaml, Bitner, and Gremler (2012), the three new marketing mix elements (people, physical evidence, and process) are included in the marketing mix as separate elements because they are within the control of the firm and because any or all of them may influence the customer's initial decisions to purchase a service as well as the customer's level of satisfaction and repurchase decisions. Furthermore, Wirtz, Chew, and Lovelock (2012) indicate that when developing ways to market manufactured goods, marketers usually focus on product, price, place (or distribution), and promotion (or communication). However, the marketing of services poses distinct marketing challenges because of the nature of services. Hence, the 4Ps of marketing are unable to deal with the issues arising from marketing services and have to be 
adapted and extended. In addition, the traditional marketing mix does not cover managing the customer interface.

Despite advances in technology, many services will always need interaction between customers and service employees (Adebayo, 2015). Hsu (2018) affirms that the interactive relationship between service providers and customers during service encounters has attracted attention over the past few years in the marketing and management literature. Due to the intangibility and inseparability of production and consumption for services which involves the simultaneous production and consumption of services, service firms depend heavily on the ability of contact employees to deliver the service (Adebayo, 2015). However, as the awareness increases, the product becomes simpler and they become off-the-shelf commodity products as noted in online marketing. Also, buyers at times prefer face-to-face interaction and they place a high premium on brand names and reliability.

From a non-profit point of view, Bromer (2013) asserts that 'people' refers to the summation of everyone that touches the organisation. According to Adebayo (2015), people could mean those who are directly or indirectly involved in the distribution of the service. People or staff are undoubtedly the lifeblood of a company and could mean subcontractors with direct interaction with customers (Fisher, 2017). For non-profit, people include constituent donors, recipients, volunteers, members, and employees. In addition, anyone who comes into contact with customers will make an impression, and that can have a profound effect, positive or negative, on customer satisfaction. The case of the church is no exception, but it will be of great value to start from the emphasis on preaching in the bible and especially in the New Testament. Jesus himself, at the opening of his ministry in the Nazareth synagogue, read from Isaiah: "The Spirit of the Lord is upon me because he has anointed me to preach the good news" (Luke 4: 18). Jesus then applied this to himself employing public exposition within the synagogue service. This simply indicates that association can be found between marketing and the church based on what influences the seller/preacher of the gospel/salvation. In addition, this influence (Holy Spirit in this regard) depicts whether the product is accepted or unaccepted, how motivated the consumers/congregations are to adapt behaviour, and the degree of religion within a consumer's/ congregation's life.

The practice of preaching cannot be separated from the person of the preacher. Considering the emphasis from the New Testament, the lifestyle and selfdiscipline of the one who brings God's message are very important. "Take heed therefore unto yourselves, and to all the flock, over which the Holy Ghost hath made you overseers, to feed the church of God, which he hath purchased with his blood," said Paul in Acts 20:28 when addressing the Ephesian elders. According to Cheeseman (1999), to be effective preachers, what one says must not be negated by the way that one lives. Paul wrote to Titus: "Show yourself in all respects a model of good deeds" (Titus 2:7). This implies that preachers' lives must match up to the doctrines they proclaim from the pulpit in order not to damage the cause of the gospel (product). One could also note that training employees for efficiency are one of the most important areas in the service industry (Van Vliet 2011). People in authority in the Christian church (Reverend, Bishop, Cardinal, Deacon, Deaconess, Evangelist, Minister, Pastor, Preacher, Choir or Usher, etc.) can also receive training and development, especially in the area of developing a strong relationship with the Holy Spirit that is, developing sensitivity to the Holy Spirit's voice. Ministerial work is also a calling that involves physical, spiritual, and mental tasks, therefore, training in the area of preaching, manner of preaching, the personality of the preacher, the sermon of a preacher (i.e., gathering of sermon materials) etc. are crucial to the delivery of a church sermon.

\section{f) Process}

According to Bromer (2013) process deals with how a service is delivered which includes measuring the success of the service, such as providing service in a timely fashion to solve a specific need. Therefore, services need to be underpinned by a clearly defined and efficient process. In other words, process means that everybody (service providers and consumers) knows what to do and how to do it. Thus, the process of a service company in delivering its product is of utmost importance. It is also a critical component in the service blueprint, wherein before establishing the service, the company defines exactly what should be the process of the service product reaching the end customers. The Chartered Institute of Marketing (2009) states that the process of providing a service and the behaviour of those who deliver it are crucial to customer satisfaction. Issues such as waiting times, the information is given to customers and the helpfulness of staff are all vital to keeping customers happy. Furthermore, in a service situation customers are likely to have to queue before they can be served and the service delivery itself is likely to take a certain length of waiting time. Wilson, Zeithaml, Bitner, and Gremler (2012) state that the actual delivery steps that the customer experiences, or the operational flow of the service, also give customers evidence on which to judge the service. Some services are very complex, requiring the customer to follow a complicated and extensive series of actions to complete the process.

Given these, the spiritual context of how it costs people to become a Christian or obtain spiritual product involves a process. This context is consistent with circumstantial evidence that except a person be born 
again, he/she cannot see the kingdom of God (John 3:3). This implies that salvation stands as the first step a person must take before they can have access to all the benefits of the kingdom of God. In addition, the kingdom of God is a process that starts with righteousness, followed by peace, and then comes joy in the Holy Ghost. It has been noted that seeking the kingdom of God as a priority is important to God (Matthew 6:33). The verse assures that it will cost one to deny oneself of some things such that one's personal needs and challenges must not be placed above the kingdom, and all other things will be added on to one. A preacher and the level of anointing are also worthy of note in the context of the process. It has been established that the greater the anointing, the greater the exploit for God, comparing it with the analysis of value proposition where marketing offers that the greater the value of a product, the higher the price. One question that could be generated in this aspect is how does a Christian/preacher obtain greater anointing?

Relationship marketing and customer relationship management can help answer the aforementioned question. Relationship Marketing (RM) and Customer Relationship Management (CRM) both represent a paradigm shift in traditional marketing thinking. Thus, the process in the spiritual context can be rewarded as having a relationship with God. According to the book of 1 John chapter 1 verse 3, "We proclaim to you what we have seen and heard, so that you also may have fellowship with us. And our fellowship is with the Father and with his Son, Jesus Christ". In addition, having a profitable life in Christ as a Christian/preacher implies a life that is surrendered to the Lord (Mark 8:36: "For what shall it profit a man, if he shall gain the whole world, and lose his soul?").The process involves one being willing to die daily; this means that one's self-will is subjected to the Master on a daily basis which Palmatier (2008) termed "relationalbased exchange". One must be ready to tear off one's old garments and get into new garments (costs) (Mark 8:37: "Or what shall a man give in exchange for his soul?"). However, a love relationship is could be added to the process, which can bring about clear communication with God in the spiritual realm. This is revealed in the book of John chapter 10 verse 27: "My sheep listen to my voice; I know them, and they follow me", which Palmatier (2008) considers as an interpersonal relationship from the perspective of customer relationship management - involving managing detailed information about individual customers.

\section{g) Physical evidence}

According to Kotler and Keller (2012) unlike physical products, services cannot be seen, tasted, felt, heard, or smelled before they are bought. A service cannot be experienced before it is delivered. Therefore, choosing to use a service can be perceived as a risky business because you are buying something intangible. Wirtz, Chew, and Lovelock (2012) raise the point that if the service requires customers to enter the service factory, it is important to start thinking about the design of the physical environment. The appearance of the buildings, landscaping, vehicles, interior furnishings, equipment, staff members' uniforms, signs, printed materials, and other visible cues provide tangible evidence of a firm's service quality. Fisher (2017) agrees that business assets are effectively used to market business, brand personality should be a pervasive consideration when choosing organisations' furniture, fittings, computer equipment, stock, publications, and brochures.

One could add that physical evidence is critical in guiding customers through the purchase process and making them feel comfortable and trusting toward the service provider. Mike (2020) supports that physical evidence includes the things customers see when interacting with a business and it gives some solid knowledge of the organisation's product or service for first-time customers. However, some churches must provide some physical evidence to showcase their theological practices. The important touch of this study is to understand the way a church service provider presents an intangible offering to the target consumer (unsaved) or to provide an understanding of what is to be done to convince the unsaved or the needy to attend church services. In the case of the church, having expectations depends on many variables, particularly having expectations of God, i.e., the promises of God, levels of interaction/communication between God and a believer, and the integrity of the one giving the promise (God) as seen in the book of Numbers 23:19 that "God is not a man that should lie". Thus, physical evidence, in this sense, conforms to the definition provided by Zeithaml, Bitner, and Gremler (2009:25) that physical evidence is the environment in which the service is delivered and where the firm and consumer interact, and any tangible components that facilitate performance or communication of the service.

\section{Methodology}

The study centres on a secondary source of data, associated with a literature review of existing data. The secondary data which constitute the core of the literature review are drawn from textbooks, journals, articles, previous researches, and internet sources (Appiah et al., 2013). The notion behind the use of secondary data is to establish the theoretical underpinning of the effective and non-effective use of marketing by churches.

\section{Conclusion}

The service sector is nothing new, as evidenced in the academic literature, and today most products 
include some element of service in them. However, there are various services in church organisation such as anointing services, Holy Communion service, Sunday school service, worship service, deliverance services, healing services, and Holy Ghost service, etc. It has also been noted in this review that services, in effect, are vital for creating 'value in use' for goods, and goods effectively become a subsidiary part of a service offer. Not only these, but it has also showcased an extended mix for service marketing where the differences between goods and services are explored. In this regard, the article has critically defined the role of marketing for different types of services. It should be apparent, therefore, that there are many ways in which the marketing of a pure good is likely to differ from the marketing of pure service. According to Palmer (2011), the principle of the extended marketing mix (as indeed with the traditional marketing mix) is to break a service offering down into several component parts and to arrange them into manageable subject areas for making strategic and tactical decisions. The influence of marketing on non-profit issues has been identified in this review. The scope and characteristics of marketing as it pertains to non-profit organisations, including the church, could be another study for consideration.

\section{References Références Referencias}

1. Abon, J.K. (2020). A marketing framework for improved competitive advantage of professional football clubs in KwaZulu-Natal, South Africa. Unpublished doctoral thesis, Durban University of Technology, Durban, South Africa.

2. Abon, J.K. and Adebayo, R.O. (2020). The use of marketing as a tool for competitive advantage among potential and professional football clubs in KZN, South Africa. Eurasian Journal of Business and Management, 8(4), 2020, pp. 319-335.

3. Adebayo R.O. (2015). The use of marketing tactics by the church in fulfilling its social mandate in KwaZulu-Natal. Unpublished doctoral thesis, Durban University of Technology, Durban, South Africa.

4. Adebayo R.O. and Zulu S.P. (2019). Miracle as a spiritual event and as a marketing tactic among Neo-Charismatic churches: a comparative study. Journal for Christian Scholarship (Tydskrif Vir Christelike Wetenskap). 55(1-2): $105-125$.

5. Adebayo, R.O. (2019). Commoditisation, materialism, and Pentecostal Christian churches. Alternation Special Edition 29: pp. 125 - 148.

6. Adebayo, R. O., and Govender, J. P. (2020). Marketing as an enabler for churches to fulfill their social responsibility. Journal for the Study of Religions and Ideologies, 19(55), 3-19.

7. Adebayo R.O. (2020). Shopping for Salvation: A Comparative Appraisal of the Place of Worship and
Marketplace in South Africa," International Journal of Religious Tourism and Pilgrimage: Vol. 8(8): pp 57-69.

8. Amelia, R.L. and Tonya, D. A. (2010). Moving the church to social action. Journal of the North American Association of Christians in Social Work, 37(2): pp. 115-127.

9. An, D. (2014). Tangibilizing services through visual tangible cues in corporate web sites: a six-country cross-cultural analysis. Journal of Services Marketing, 28(7): pp. 566-579.

10. Appiah, S., Dwomoh, D. and Kyire, L.A. (2013). The relationship between church marketing and church growth: evidence from Ghana. Global Journal of Management and Business Research Marketing, 13(10): 8-16.

11. Beckwith, H. (2013). Selling the invisible - highlights (online). Available: http://www.kcapital-us.com/ harry/ sti_high-pdf (Accessed 12 September 2020).

12. Black, H.G., Childers, C.Y. and Vincent, L.H. (2014). Service characteristics' impact on key service quality relationships: a meta-analysis. Journal of Services Marketing, 28(4): pp. 276-291.

13. Blake, C.H. (2021). Exploring leadership attitudes and behaviours: Social media marketing and digital technology strategies and the church. Doctoral Dissertation, South University.

14. Boundless. (2014). Intangibility. (online). Available: https://www.boundless.com/marketing/textbooks/bo undless-marketing-textbook/services-marketing (Accessed 25 November 2020).

15. Brandenberg, D. (2014). Service marketing vs. product marketing in hotels (online). Available: http://smallbusiness.chron.com/service-marketingvs-product-marketing-hotels-23637.html (Accessed 20 November 2020).

16. Bromer, C. (2013). For-Profit thoughts for a nonprofit world: Marketing "7 P's" - The relevance for non-profits (online). Available: http://craigbromer. com/2013/05/marketing-7-ps-the-relevance-fornonprofits/ (Accessed February 2021).

17. Chartered Institute of Marketing (2009). Marketing and the 7Ps: A brief summary of marketing and how it work. Available at: https://www.cim.co.uk/media/ 4772/7ps.pdf. (Accessed18 October 2020).

18. Cheeseman, J. (1999). The priority of preaching (online). Available: http://archive.churchsociety.org/ churchman/documents/Cman_113_4_Cheeseman. pdf (Accessed 21 January 2021).

19. David, M. (2014). Why men aren't buying the church's core product (Part 1). The American Church Magazine (online). Available: http://church formen.com/products-page/ 13-14, (Accessed January 2021).

20. Desa, N. (2013). What is the Spiritual Significance of Places of Worship? (online). Available: http:// 
www.quora.com/What-is-the-spiritual-significanceof-places-of-worship (Accessed 06 October 2020).

21. Donovan, R. and Henley, N. (2010). Principles and practice of social marketing: an international perspective. London: Cambridge University Press.

22. Engelland, B.T. (2014). Religion, humanism, marketing, and the consumption of socially responsible products, services, and ideas: Introduction to a special topic section. Journal of Business Research. 67(2): pp. 1-4.

23. Fisher, K. (2017). The 7P's of Marketing: People, processes \& physical evidence. Simply successful marketing (online). Available: https://irpcdn.multiscreensite.com/cd5aeb4e/files/uploaded/

MA57-The-7-ps-of-marketing.pdf (Accessed 07 May 2021).

24. Gawroński, S. and Majkowska, I. (2018). Marketing Communication of the Catholic Church - a Sign of the Times or Profanation of the Sacred? Studia Humana. Vol. 7(2): pp. 15-23 DOI: 10.2478/sh-20180007.

25. Hult, G.T.M., Pride, W.M., and Ferrell, O.C. (2012). Marketing. Mason, $\mathrm{OH}$ : South-Western, Cengage Learning.

26. Hsu, L. (2018). Investigating effect of service encounter, value, and satisfaction on word of mouth: An outpatient service context. International Journal of Environmental Research and Public Health. 15(132): pp. 1-15 doi:10.3390/ijerph150 10132.

27. Johnston, K. (2014). Selling a product vs. selling a service (online). Available: http://smallbusiness. chron.com/selling-product-vs-selling-service55446.html (Accessed 8 September 2020).

28. Kar, A. (2010). The 7P's of service marketing. [online]. Available at: <http://businessfundas.com/ 2010/the-7-ps-of-services-marketing/> [Accessed 25 July 2020].

29. Kioulachoglou, T. (2018). Freely you Received, Freely you Give. The Journal of Biblical Accuracy. Available at: http://www.jba.gr/. (Accessed 28 July 2020).

30. Kotler, P. and Armstrong G.M. (2012). Principles of marketing. 14th ed. United Kingdom Pearson Education Ltd.

31. Kotler, P. and Keller, K.L. (2012). Marketing management. 14th ed. Upper Saddle River, NJ: Pearson Prentice Hall.

32. Lamb, C.W., Hair, J.F. and McDaniel, C. (2013). MKTG6. South-Western, Cengage Learning.

33. Lee, N. and Kotler, P. (2011). Social marketing: influencing behaviors for good. Social Marketing Services Inc. Sage (online). Available: www.social marketingservice.com (Accessed February 2021).

34. Lee, D., Hosanagar, K., and Nair, H. S. (2018). Advertising content and consumer engagement on social media: Evidence from Facebook. Management Science, 64(11), 5105-5131.

35. Mike (2020). Basic Principles of Marketing (online). Available: https://whatagraph.com/blog/articles/prin ciples-of-marketing (Accessed 07 May 2021).

36. Moeller, S. (2010). Characteristics of services - a new approach uncovers their value. Journal of Services Marketing, 24(5): 359 - 368.

37. Njoh, A. J. (2012). The impact of religion on women empowerment as a millennium development goal in Africa. Social Indicators Research, 107(1): pp. 1-18.

38. Palmer, A. (2011). Principles of Services Marketing. 6th revised ed. Maidenhead, UK McGraw Hill Higher Education.

39. Palmatier, R. W. (2008). Relationship marketing. Marketing Science Institute, Cambridge, Massachusetts. 1-86.

40. Pink, A.W. (2014). The attributes of God (online). Available: http://www.gracegems.org/Pink/attribu tes_of_god9.htm (Accessed 2 December 2020).

41. Rothschild, M. L. (2009). Separating products and behaviours. Social Marketing Quarterly, 15(1): 107-110.

42. Roy, S. and Sivakumar, K. (2014). Which controls are better for service outsourcing? Integrating service-dominant logic and service characteristics. AMS Review, 4(3-4):45-62.

43. Senthil, K., Dharmalingam, S., and Panchantham, N. (2011). Strategies for service characteristics of star hotel. The Journal of Commerce, 3(1): 37-42.

44. Shawchuck, N., Kotler, P., Wrenn, B. and Rath, G. (1992). Marketing for congregations: choosing to serve people more effectively. Nashville: Abingdon Press.

45. Shimp, T.A. and Andrews, J.C. (2013). Advertising, promotion, and other aspects of integrated marketing communications. Mason, $\mathrm{OH}$ : SouthWestern: Cengage Learning.

46. Suri, R. and Rao, J. (2014). Impact of spiritual marketing on different segments of tourists and their evaluation of thesite. Journal of Business \& Economic Policy 1(1): 26-34.

47. Strydom, J. (2011). Introduction to Marketing. Cape Town: Juta and Company Ltd.

48. Simões,C. and Nascimento-e-Silva, D. (2020). Legal marketing: Proposing an operational definition. IOSR Journal of Humanities And Social Science (IOSR-JHSS). Vol. 25(7): pp. 59-67.

49. Thackeray, R. and Brown, K.R. (2010). Creating successful price and placement strategies for social marketing. Health Promot Pract, 11(2): pp. 166-168.

50. The Chartered Institute of Marketing (2009). Marketing and the 7Ps: A brief summary of marketing and how it works (online). Available: www.cim.co.uk/marketingresurces/. (Accessed 25 May 2020). 
51. Vance, M. (2014). The inseparability of services: marketing concepts (online). Available: http://rmsbunkerblog.wordpress.com/2014/03/13/th e-inseparability-of-services-marketing-concepts/ (Accessed 15 November 2020).

52. Van der Merwe, M.C., Grobler, A.F., Strasheim, A. and Orton, L., (2013). 'Getting young adults back to church: a marketing approach'. HTS Teologiese Studies/Theological Studies 69 (2). Available: http://dx.doi.org/10.4102/hts.v69i2.1326 (Accessed 12 August 2020).

53. Van Vliet, V. (2011). Service marketing mix - 7Ps (online). Available: http://www.toolshero.com/ service-marketing-mix-7ps (Accessed 14 June 2020).

54. Wilson, A., Zeithaml, V.A., Bitner, M.J. and Gremler, D.D. (2012). Services marketing integrating customer focus across the firms. 2nd ed. New York, McGraw-Hill.

55. Zeithaml, V.A., Bitner, M.J. and Gremler, D.D. (2009). Services marketing: integrating customer focus across the firm. 5th ed. New York: McGrawHill Education. 